\title{
BLACK SOLDIER FLY: AN INDUSTRIAL INSECT
}

\author{
HARSH B. PATEL ${ }^{1 *}$, D. B. SISODIYA ${ }^{1}$, P. K. BORAD ${ }^{1}$ \& RAGHUNANDAN, B.L. ${ }^{2}$ \\ ${ }^{1}$ Department of Agri. Entomology, B. A. College of Agriculture, Gujarat, India \\ ${ }^{2}$ AICRP on Biological Control of Crop Pests, Anand Agricultural University, Gujarat, India
}

\begin{abstract}
The total worth of food waste is \$1 trillion in world and every year about 350 million tonnes organic waste is produced from agricultural source in India. Generally we are utilized agricultural waste as fuel, biogas production, farm manure etc. In today's scenario,agro-waste management is global level issue and black soldier fly (BSF) farming is novel approach/weapon against this issue. BSF can produce 80 times much protein as compared to broiler chickens from one acre of land. BSF farming is a good entrepreneurship under Make in India, Startup India, SwachhBharat mission and can help to bring prosperity among the rural people.
\end{abstract}

KEYWORDS: Black soldier fly, Industrial insect, life cycle, Agricultural waste, Industrial application

Received: Nov 18, 2020; Accepted: Dec 09, 2020; Published: Jan 08, 2021; Paper Id.: IJASRDEC20207

\section{INTRODUCTION}

Hermetia illucens (L.)commonly known as black soldier fly (BSF) belongs to family Stratiomyidae, order diptera. It is native to America reported in tropical, sub-tropical and warm temperate zones. It had spread to Europe, Asia, India, and Australia during the time of World War II. As the larvae usually found in abundance around the manure piles of poultry, pigs and cattle, it is also known by the name "latrine larvae. BSF larvae are very efficient to convert organic waste.It consumes manure and convert the nutrients into larval body mass, which contains $>40 \%$ protein and $>30 \%$ fat; thus a source of potential high protein, high energy animal feed can be prepared and thereby in the process, manure mass can be reduced about 50\% (Newton et al., 2005). Besides it is also a source of biodiesel. BSF can be used as industrial insect for animal feed, decomposing agent and biofuel production.

\section{Life cycle}

BSF has complete metamorphosis. Female adult lays eggs on surfaces or adjacent to decaying matter or in crevices to protect from predators, dehydration by direct sunlight which ensures the neonate larvae have first food source nearby after hatching. Egg is creamy white in colour with $1 \mathrm{~mm}$ length and incubation period is about 4 days (Park, 2016). Larva is creamy white with $1 \mathrm{~mm}$ to $25 \mathrm{~mm}$ length and undergo through six larval instars in 13 to 18 days. It feed voraciously on the decaying matter. Under unfavourable conditions it has the ability of extend its life cycle which considered it as resilient organism (Dortmans et al., 2017). During the larval development, enough fat and protein reserves help larvae to undergo pupation, fly emergence and reproduction. The presence of thin grey-black stripe on their posterior ends differentiates the BSF larvae from blowfly or housefly larvae. Body is pale white colour with small black head (Newton et al., 2005). Fully developed larva under goes pupation in decaying matter. Pupa is dark black in colour and thepupal period is 10 to 30 days. Adult measured 15-20 mm long having predominating metallic black body ranging from blue to green on the thorax and some time the abdomen with a reddish 
end. Female adult have reddish colour and male adult have more bronze. Fecundity was 400-800 eggs/female and theyprefer the light of morning hours to copulate.Adult do not feed and requires source of water or a humid surface to stay hydrated and abundant amount of natural light and a warm temperature $\left(25-32^{\circ} \mathrm{C}\right)$. It mimics in size, colour and appearance to the organ pipe mud dauber wasp and its relatives.In the south-eastern United States three generations have been documented in a year and it can be collected from late spring through early fall (Sheppard et al. 1994).

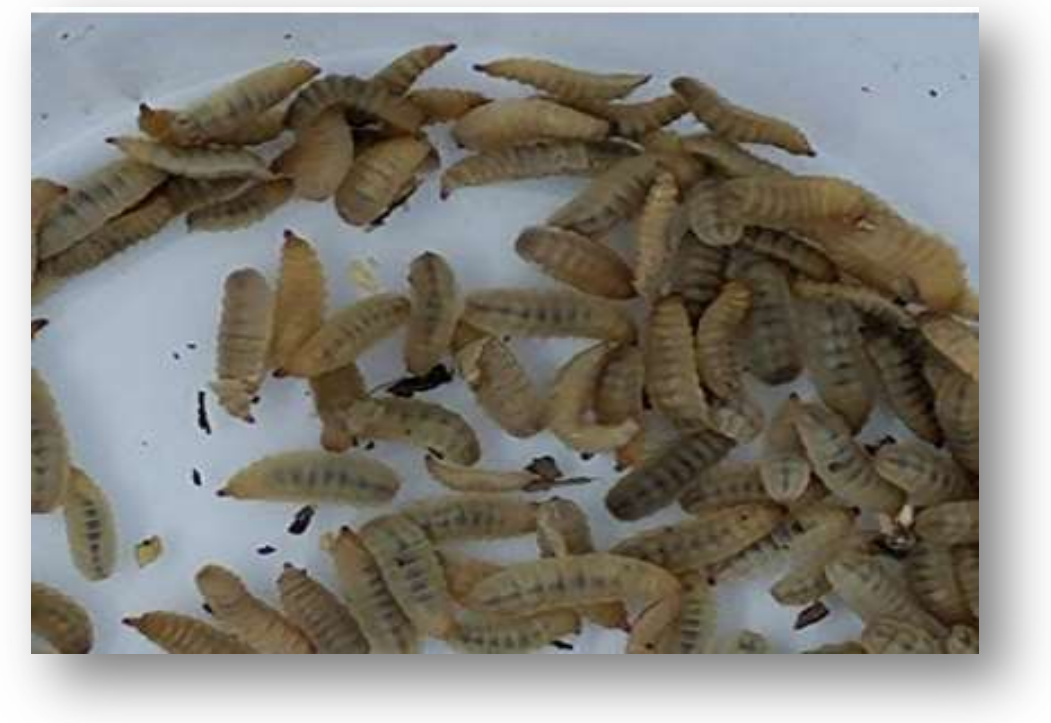

Figure 1: Black soldier fly larvae
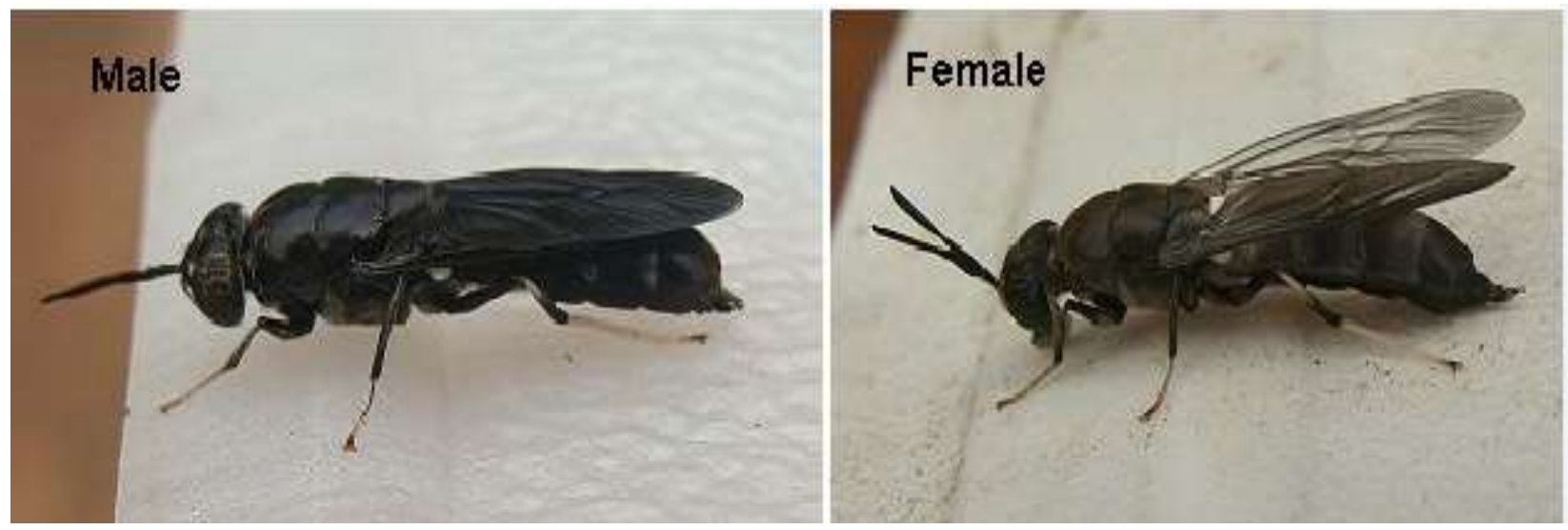

Figure 2: Adults of black soldier fly

\section{Mass production technique}

Love cages, attractant cages, dark cages, egg colonies, water bowls, hammer mill, stack of larveiors, mobile frame and artificial lights are required for mass production of BSF. During prepupal stage diet had not significantly influence the development or survivorship (Tomberlin et al., 2002). It was mass produced on pig manure (swine system) and poultry manure (layer hens system) at USA (Newton et al., 2005). In Italy it was also mass reared on fruit and vegetable wastes (Meneguz et al., 2018).

\section{Industrial applications}




\section{(1) For the preparation of food stuff of pet animals}

Dried larvae of BSF contain higher crude protein (42.1\%), ether extract (34.8\%), crude fibre (7\%), calcium (5\%) which generally used for swine diet (Newton et al., 1977). BSF larval meal was valuable feed stuff for catfish and tilapia(Bondari \& Sheppard, 1981; Sealey et al., 2011). BSF larval frass with wheat middling was good diet for fresh water prawn (Tiu, 2012). BSF maggot meal (50\%) can be used as substitute feed stuff of fish meal protein in quail diet (Widjastuti et al., 2014). The meal of black soldier fly can be valuable component of layer diets and insect meal production. The production of this insect will become economically viable through upscaling (Maurer et al., 2016). BSF prepupae is arich source of different amino acid (18), Mineral (9), fatty acid (14), crude protein (42.1\%) and crude fibre (7\%) which can be utilized for preparation of food stuff of pet animals (Anonymous, 2019b).

\section{(2) For waste management}

No extra facility or added energy is required for the manure management system for laying hens using BSF larvae reduced manure accumulation by at least 50\% (Sheppard \& Newton, 1994). Within a short time a daily rate of $100 \mathrm{mg}$ chicken feed per BSF larva met the demand for a nutrient-rich prepupal output and high organic matter degradation as well (Diener et al., 2009). BSF larvae had a great potential in organic waste management (Diener et al., 2011). BSF prepupa which was reared on dairy cattle manure and trout offal can be used to replace up to $50 \%$ of fish meal portion of Oncorhynchus mykiss diet without significantly affecting fish growth or the sensory quality (Sealey et al., 2011).

\section{(3) For biodiesel production}

Fatty Acid Methyl Ester (FAME) derived from larval lipids is feasible to be used for biodiesel production (Leong et al., 2016). Lipase catalysed conversion of BSF larval fat to biodiesel using Novozym 435 is a promising method towards producing alternative green fuel (Nguyen et al., 2017). 

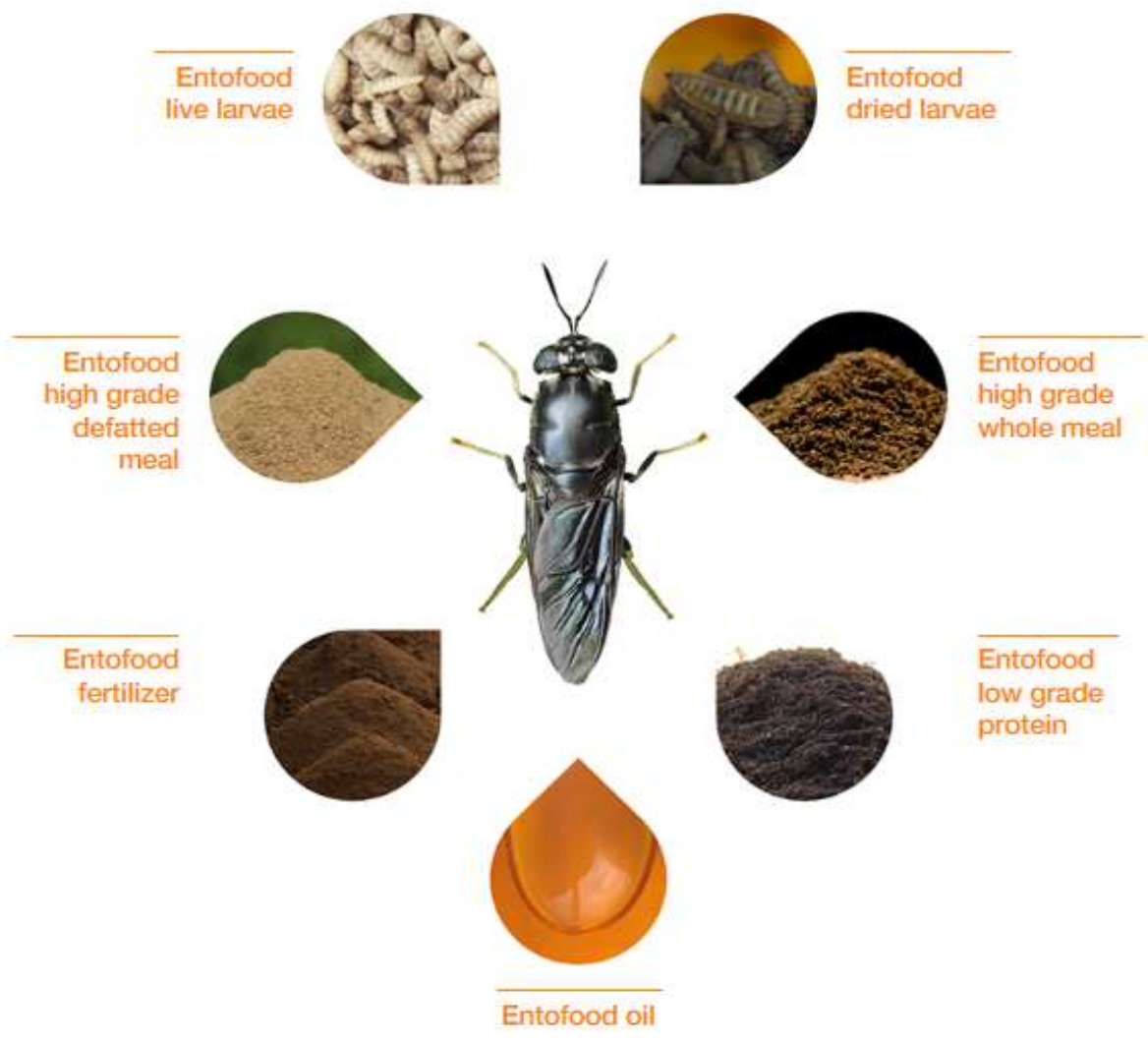

Figure 3: Industrial applications of black soldier fly (source: https://www.entofood.com)

\section{Economics}

Investment cost 85,000 \$, running cost per year 35,700 \$ and about $972 \mathrm{~m}^{2}$ area for waste decomposition were required for processing municipal organic waste@ 3 tonnes per day in Costa (Diener et al., 2009).

\section{Products available in the market}

In 2006, U.S. registered trademark was granted to first feeder insect 'phoenix worms'. NutriGrubs, Soldier Grubs, Reptiworms, Calciworms, and BIOgrubs are the different brand names of the BSF products available in the markets of different countries. In Australia, Beardie Grubs is the brand name of live feeder insect and in India as Protyn (Anonymous, 2019b; Anonymous, 2019c).

\section{CONCLUSIONS}

BSF is a good alternative source of animal protein, crude fat, crude fibre, amino acids, fatty acids, minerals for fish, prawn, layer and quail. It is a very good tool for nutritional food security and can help in solving the problem of malnutrition. It acts as weapon for manures and agro-product's waste management and a source for eco-friendly fuel production.

\section{REFERENCES}

1. Anonymous (2019a). https://time.com/3825158/farming-flies-south-africa.

2. Anonymous (2019b). https://www.protyn.io/ 
3. Anonymous (2019c). https://en.wikipedia.org/wiki/Hermetia_illucens

4. Bondari K and Sheppard DC (1981)Soldier fly larvae as feed in commercial fish production. Aquaculture. 24:103-109.

5. Chandra, G. S., M. Manamohan, and T. Sita. "Key to the successful RNA interference (RNAi) mediated management of agricultural pests." International Journal of Agricultural Science and Research (IJASR) 5.5 (2015): 191-200.

6. Diener S, Zurbrügg C and Tockner K (2009)Conversion of organic material by black soldier fly larvae: establishing optimal feeding rates. Waste Management \& Research. 27(6):603-610.

7. Diener S, Zurbrügg C, Gutiérrez FR, Nguyen DH, Morel A, Koottatep T and Tockner K (2011)Black soldier fly larvae for organic waste treatment-prospects and constraints. Proceedings of the WasteSafety. 2:13-15.

8. Dortmans BM, Diener S, Verstappen BM and Zurbrügg C (2017) Black Soldier Fly Biowaste Processing-A Step-by-Step Guide; Eawag-Swiss Federal Institute of Aquatic Science and Technology. Department of Sanitation, Water and Solid Waste for Development (Sandec): Dübendorf, Switzerland. 24-57

9. Lakshmikantham, V., and D. Bharathi. "IMPACT OF PLANT GROWTH HORMONE, INDOLE-3-ACETIC ACID (IAA) ON THE ORGANIC CONSTITUENTS OF SILKWORM, BOMBYX MORI L." International Journal of Agricultural Science and Research (IJASR) 4.5 (2014): 37-44.

10. Leong SY, Kutty SRM, Malakahmad A and Tan CK (2016) Feasibility study of biodiesel production using lipids of Hermetia illucens larva fed with organic waste. Waste management. 47:84-90.

11. Maurer V, Holinger M, Amsler Z, Früh B, Wohlfahrt J, Stamer A and Leiber F (2016) Replacement of soybean cake by Hermetia illucens meal in diets for layers. Journal of Insects as Food and Feed. 2(2): 83-90.

12. Meneguz M, Schiavone A, Gai F, Dama A, Lussiana C, Renna M and Gasco L (2018) Effect of rearing substrate on growth performance, waste reduction efficiency and chemical composition of black soldier fly (Hermetia illucens) larvae. Journal of the Science of Food and Agriculture. 98(15): 5776-5784.

13. Newton GL, Booram CV, Barker RW and Hale OM (1977) Dried Hermetia illucens larvae meal as a supplement for swine. Journal of Animal Science44(3): 395-400.

14. Newton GL, Sheppard DC, Watson DW, Burtle GJ, Dove CR, Tomberlin JK and Thelen EE (2005)The black soldier fly, Hermetia illucens, as a manure management/resource recovery tool. In: Symposium on the state of the science of Animal Manure and Waste Management pp. 5-7.

15. Nguyen HC, Liang SH, Doan TT, Su CH and Yang PC (2017) Lipase-catalysed synthesis of biodiesel from black soldier fly (Hermetica illucens): Optimization by using response surface methodology. Energy Conversion and Management 145:335342 .

16. Park, H. H. (2016). Black soldier fly larvae manual, Retrieved from https://scholarworks.umass.edu/sustainableumass_studentshowcase/14/

17. Sealey WM, Gaylord TG, Barrows FT, Tomberlin JK, McGuire MA, Ross C and St-Hilaire S (2011) Sensory analysis of rainbow trout, Oncorhynchus mykiss, fed enriched black soldier fly prepupae, Hermetia illucens. Journal of the World Aquaculture Society. 42(1):34-45.

18. Sheppard DC, Newton GL, Thompson SA, Savage S. (1994) A value added manure management system using the black soldier fly. Bioresource Technology. 50(3):275-279. 
19. Subbireddy, K. B., K. G. Kanjariya, and A. N. Tharun. "Carbon dioxide under high pressure: A safe method for the stored grain pest management." International Journal of Agricultural Science and Research 7.3 (2017): 427-432.

20. Tiu LG. (2012) Enhancing sustainability of freshwater prawn production in Ohio. Ohio State Univ. South Cent. Newsl. Fall. 11(4).

21. Tomberlin JK, Sheppard DC and Joyce JA (2002) Selected life-history traits of black soldier flies (Diptera: Stratiomyidae) reared on three artificial diets. Annals of the Entomological Society of America. 95(3):379-386.

22. Widjastuti T, Wiradimadja $R$ and Rusmana D (2014) The effect of substitution of fish meal by Black Soldier Fly (Hermetia illucens) maggot meal in the diet on production performance of quail (Coturnix coturnix japonica). Animal Science. 57:125129.

23. Veena, T., D. V. Chidanand, and K. Alagusundaram. "Quality analysis of mango fruit with fruit fly insect by nondestructive soft X-ray method." International Journal of Agricultural Science and Research (IJASR) 5.3 (2015): $37-$ 45. 